\title{
Cell population heterogeneity during growth of Bacillus subtilis
}

\author{
Daniel B. Kearns ${ }^{1,2}$ and Richard Losick ${ }^{1,3}$ \\ ${ }^{1}$ Department of Molecular and Cellular Biology, Harvard University, Cambridge, Massachusetts 02138, USA; ${ }^{2}$ Department of \\ Biology, Indiana University, Bloomington, Indiana 47405, USA
}

\begin{abstract}
We have discovered that cells of Bacillus subtilis at the mid-exponential phase of growth are a mixed population of two strikingly different cell types. One type is single swimming cells (or cell doublets) in which the transcription factor for motility, $\sigma^{\mathrm{D}}$, is active $\left(\sigma^{\mathrm{D}} \mathrm{ON}\right)$. The other type is long chains of sessile cells in which $\sigma^{\mathrm{D}}$ is inactive $\left(\sigma^{\mathrm{D}} \mathrm{OFF}\right)$. The population is strongly biased toward $\sigma^{\mathrm{D}}$-ON cells by the action of a novel regulatory protein called SwrA. SwrA stimulates the transcription of a large operon /the flagellum/chemotaxis operon), which includes the genes for $\sigma^{\mathrm{D}}$ and an activator of $\sigma^{\mathrm{D}}$-directed gene expression, SwrB. Cell population heterogeneity could enable $B$. subtilis to exploit its present location through the production of sessile cells as well as to explore new environmental niches through the generation of nomadic cells.
\end{abstract}

[Keywords: Motility; bistability; SwrA; $\sigma^{\mathrm{D}}$; swarming; flagella]

Supplemental material is available at http://www.genesdev.org.

Received September 12, 2005; revised version accepted October 27, 2005.

Microbiologists have traditionally viewed populations of genetically identical bacteria as if they were homogeneous. Increasingly, however, it has become apparent that under certain conditions certain populations of bacteria are heterogeneous, consisting of mixtures of cells in decidedly distinct physiological or developmental states. For example, Escherichia coli cells can spontaneously enter a "persister" state in which some cells in the population temporarily stop growing and, as a consequence, escape the killing action of $\beta$-lactam antibiotics (Balaban et al. 2004; Keren et al. 2004). Similarly, under conditions of nutrient limitation, cells of Bacillus subtilis generate a mixed population in which about half of the cells activate the master regulator for sporulation, Spo0A, and the remainder do not (Chung et al. 1994; González-Pastor et al. 2003; Fujita et al. 2005). The biological significance of this example of population heterogeneity is that cells that have activated SpoOA delay becoming committed to spore formation by a process of cannibalism that involves the killing of sibling cells that have not activated the master regulator (González-Pastor et al. 2003)

Yet another example of population heterogeneity is seen during the transition to stationary phase under conditions in which cells of $B$. subtilis enter a physiological state known as genetic competence. Competent cells cease growth and become capable of undergoing DNA-

${ }^{3}$ Corresponding author.

E-MAIL losick@mcb.harvard.edu; FAX (617) 496-4642.

Article and publication are at http://www.genesdev.org/cgi/doi/10.1101/ gad.1373905. mediated transformation. During the transition to stationary phase, only some cells in the population $(10 \%-$ $20 \%$ ) activate the master regulator for competence, ComK, and become competent (Hadden and Nester 1968; Haseltine-Cahn and Fox 1968; Haijema et al. 2001). In this manner only a fraction of the cells sacrifice their ability to grow in order to gain the benefit of DNA uptake. The remainder of the cells can continue to grow or alternatively respond to stationary phase in other ways such as the process of sporulation mentioned above.

Here we report the discovery of a new and striking example of cell population heterogeneity that is seen during the exponential phase of growth. We show that growing cells of $B$. subtilis exist in one of two states with respect to the expression of genes involved in motility. Cells of $B$. subtilis swim by means of a flagellum, the protein components of which are partly encoded by a large (31-gene-long) operon (the fla/che operon) that includes flagellum genes, genes involved in chemotaxis, and the gene for the alternative sigma factor $\sigma^{\mathrm{D}}$, the penultimate member of the operon (Fig. 1; Helmann et al. 1988; Márquez et al. 1990; Zuberi et al. 1990; Albertini et al. 1991). The $\sigma^{\mathrm{D}}$ factor, in turn, directs the transcription of the remaining genes involved in flagellum biosynthesis, which lie outside the operon. These include hag, the structural gene for the flagellar filament, and $f l g G$ and $f l g K$, which encode major components of the flagellar hook-basal body (Mirel and Chamberlin 1989; Chen and Helmann 1994; Mirel et al. 1994; Serizawa et al. 2004). The $\sigma^{\mathrm{D}}$ factor also directs the transcription of genes $\left(l_{y t C}, l_{y t D}\right.$, and $\left.l y t F\right)$ for autolytic enzymes that mediate 


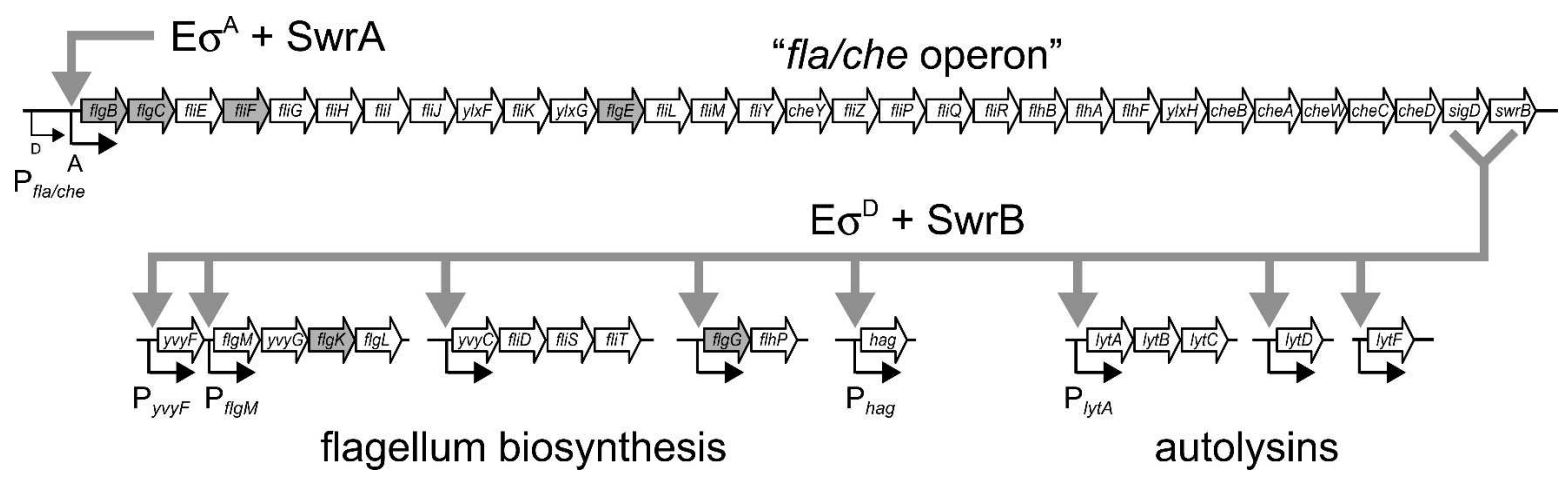

Figure 1. The regulation and genetic organization of motility and autolysin genes in B. subtilis. Open arrows represent open reading frames. Gray arrows represent open reading frames encoding major components of the flagellum hook-basal body complex. Bent black arrows represent promoters. Bent gray arrows represent the regulatory chain that governs transcription from the indicated promoters.

the separation of sister cells after cell division (Fig. 1; Lazarevic et al. 1992; Margot et al. 1994, 1999; Blackman et al. 1998).

We now show that growing cells of $B$. subtilis are a mixed population in which $\sigma^{\mathrm{D}}$ is active $(\mathrm{ON})$ in some cells and inactive (OFF) in other cells. When $\sigma^{\mathrm{D}}$ is $\mathrm{ON}$, individual cells are motile, whereas when $\sigma^{\mathrm{D}}$ is OFF, cells grow as long sessile chains. We show that the population is strongly biased toward swimming cells by a novel regulatory protein called SwrA that stimulates the transcription of the fla/che operon, which includes the gene for $\sigma^{\mathrm{D}}$ and the gene for a novel protein called SwrB (Fig. 1). We further show that SwrB is an activator of $\sigma^{\mathrm{D}}$-directed gene expression and that biasing the cell population to the $\sigma^{\mathrm{D}}$-ON state requires high-level expression of the genes for both $\sigma^{\mathrm{D}}$ and SwrB. Finally, we speculate on the nature of the mechanism that switches $\sigma^{\mathrm{D}}$ activity ON or OFF and the biological significance of the alternative cell types.

\section{Results}

Growing cells exist in two alternative developmental states

Laboratory strains of B. subtilis, such as 168 and PY79, are traditionally recognized as existing in one of two morphologically distinct forms (Fein 1979). One form is characterized by long chains of sessile cells, and this is the predominant form seen during the exponential phase of growth, as illustrated in Figure 2A. The other form is represented by single cells or cell doublets that are motile. Motile cells represent a small proportion of the population during growth but are known to become prevalent during the transition to stationary phase (Nishihara and Freese 1975).

While studying the wild $B$. subtilis strain 3610 , we noticed that the relative proportion of the two cell forms was dramatically different from that of the laboratory strains. Instead of long chains of sessile cells, we principally saw motile cells that were present as single cells or pairs (Fig. 2B). It is thought that the wild strain 3610 is an ancestor to the laboratory strain PY79 and that during domestication various multicellular behaviors, such as the capacity to form architecturally complex communities of cells (biofilms) and to form rafts of swarming cells on surfaces, were lost (Branda et al. 2001; Kearns and Losick 2003). It now seems that the two strains also differ with respect to their cell population biases between the states of swimming and chaining.

Cell chaining and motility are controlled by the alternative sigma factor $\sigma^{\mathrm{D}}$, which governs motility and the production of autolysins involved in cell separation (Helmann et al. 1988; Márquez et al. 1990; Blackman et al. 1998; Serizawa et al. 2004). We therefore wondered whether the difference between the long chains of sessile cells and the motile cells was reflected in the activity of $\sigma^{\mathrm{D}}$. To monitor $\sigma^{\mathrm{D}}$-directed gene transcription, we created a reporter construct $\left(\mathrm{P}_{\text {hag }}-g f p\right)$ in which the gene for the green fluorescent protein was fused to a strong promoter $\left(\mathrm{P}_{\text {hag }}\right)$ for a gene (hag) under $\sigma^{\mathrm{D}}$ control (Mirel and Chamberlin 1989). Indeed, the two cell types differed sharply with respect to the activity of the alternative $\sigma$ factor. Whereas single cells and cell doublets were brightly fluorescent, little fluorescence was detected in the cell chains. This was true both for the laboratory strain (Fig. 3A), where cell chains were the predominant form, and for the wild strain (Fig. 3B), where motile cells were the predominant form. As a control, cells mutant for $\sigma^{\mathrm{D}}$ grew almost exclusively as long chains and failed to express the $\mathrm{P}_{\text {hag }}-g f p$ reporter (Figs. $2 \mathrm{~K}, 3 \mathrm{~K}$ ). We conclude that sessile cells and motile cells represent alternative developmental states that coexist during the exponential phase of growth and differ with respect to $\sigma^{\mathrm{D}}$ directed gene transcription.

\section{SwrA biases cells to the swimming state}

Next, we wanted to determine the basis for the striking difference between wild and laboratory strains in the proportions of cells in the two developmental states. Laboratory strains typically carry a frameshift mutation in $s w r A$, a gene of unknown function that is required for swarming motility (Kearns et al. 2004; also referred to as swrAA, Calvio et al. 2005). We therefore wondered whether SwrA was responsible for the high bias toward motile cells in the 3610 wild strain. Indeed, the introduction of a swrA mutation into 3610 caused a dramatic 


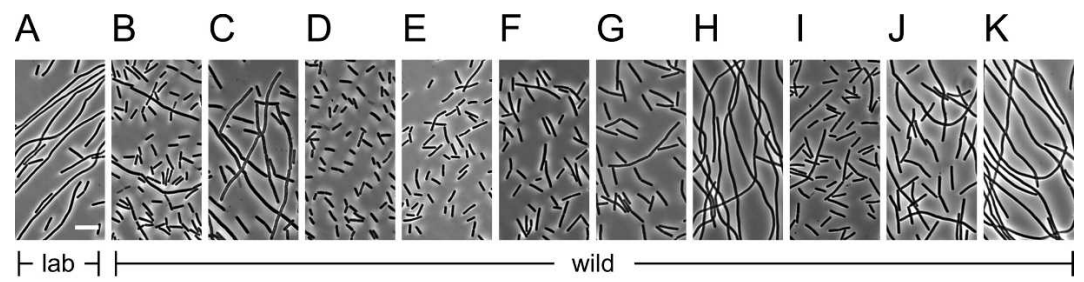

Figure 2. Populations of B. subtilis cells consist of two morphologically distinct forms. Phase contrast micrographs were taken of mid-exponential phase $\left(\mathrm{OD}_{600}=1\right)$ cultures of the following strains: PY79 $(A), 3610(B)$, DS215 $(C)$, DS526 $(D), \operatorname{DS} 726(E), \operatorname{DS} 934(F)$, DS1488 (G), DS1489 (H), DS1512 (I), DS1539 $(J)$, and DS1543 $(K)$. Bar, $5 \mu \mathrm{m}$. PY79 is a laboratory strain, and 3610 is a wild strain. The strains in $C-K$ were derived from 3610 . The cell population distribution data presented in the graph were obtained from cells represented in the correspondingly labeled panels of micrographs that had been treated with the membrane stain FM4-64 and visualized by fluorescence microscopy. Isolated single cells and cells in pairs were enumerated and categorized as "singlets and doublets." Cells in chains of four or more individuals were enumerated and categorized as "chains." Finally, the number of cells in singlets and doublets and the number of cells in chains were divided by the total number of cells and converted into a percentage. At least 800 cells were counted for each strain.

increase in the proportion of cells in the sessile, chaining state (Fig. 2C). Moreover, cell chains from the swrA mutant derivative of 3610 exhibited only a low level of expression from the $\mathrm{P}_{\text {hag }}-g f p$ reporter (Fig. 3C). Thus, the introduction of a SWrA mutation had caused the otherwise wild strain to closely resemble the laboratory strain PY79 both with respect to cell chaining and $\sigma^{\mathrm{D}}$ activity. As a control, a reporter construct $\left(\mathrm{P}_{\text {hy-spank }}{ }^{\mathrm{C}}-g f p\right)$, in which the gene for the green fluorescent protein was fused to a promoter $\left(\mathrm{P}_{\text {hy-spank }}{ }^{\mathrm{C}}\right)$ that is constitutive and under the control of $\sigma^{\mathrm{A}}$, was introduced into the swrA mutant derivative of 3610 . Figure $3 \mathrm{~L}$ shows that the $\mathrm{P}_{\text {hy-spank }} \mathrm{C}_{-g f p}$ construct was expressed at similar levels in single cells and in cell chains. Thus, the block in $\sigma^{\mathrm{D}}$ directed gene transcription did not reflect a general defect in gene expression or a limitation in the capacity to detect green fluorescence in cell chains.

Finally, as evidence that the population bias was a feature of cells in the exponential phase of growth, similar results were obtained at early $\left(\mathrm{OD}_{600}<0.3\right)$ and late $\left(\mathrm{OD}_{600}=1.0\right)$ stages of the exponential phase of growth, and this was true both in the case of the wild type and in the case of the SwrA mutant (Supplementary Fig. S1). Also, to ensure that cells were truly in the exponential phase of growth, the cultures of the experiment of Supplementary Figure S1 were inoculated by a 20 -fold dilution from cell cultures that were themselves at the mid-exponential phase of growth.

We conclude that $B$. subtilis exists in two alternative developmental states during the exponential phase of growth. The two states are governed by the activity of $\sigma^{\mathrm{D}}$, being either ON or OFF. Cells in which $\sigma^{\mathrm{D}}$ activity is $\mathrm{ON}$ express autolysin and flagellum biosynthesis genes and are characterized by being motile and undergoing cell separation. Cells in which $\sigma^{\mathrm{D}}$ activity is OFF fail to express these genes and grow as long, nonmotile chains. SwrA biases population heterogeneity in the direction of cells in which $\sigma^{\mathrm{D}}$ activity is ON. Thus, in the absence of SwrA, the cells are chiefly in the $\sigma^{\mathrm{D}}$-OFF state, whereas in the presence of SwrA, cells are principally in the $\sigma^{\mathrm{D}}$-ON state.

\section{Overexpression of swrA eliminates the lag in the transition to swarming}

To investigate further the role of $s w r A$ in cell chaining, a strain was constructed in which SwrA was overexpressed as a consequence of being fused to a strong, $\sigma^{\mathrm{A}}$ recognized promoter $\left(\mathrm{P}_{\text {hy-spank }}\right)$. In contrast to the predominance of chains observed for the swrA mutant and the preponderance of swimming cells observed for strains that were wild type for $s w r A$, a strain in which SWrA was overexpressed generated few, if any, chains (Fig. 2D). Instead, the population consisted almost entirely of single, swimming cells that uniformly exhibited a high level of $\sigma^{\mathrm{D}}$-directed gene transcription (Fig. 3D). In addition, overexpression of $s w r A$ resulted in a striking overproduction of flagella (Fig. 4).

During swarming motility, B. subtilis cells become hyperflagellated, resembling cells in which $s w r A$ has been overexpressed (Kearns and Losick 2003; Senesi et al. 2004). To test the consequences of varying SwrA levels on swarming motility, the overexpression construct described above in which swrA expression is under the control of an IPTG-inducible promoter, was introduced into a swrA mutant background, and the levels of swrA expression were varied by adjusting the amount of inducer (IPTG) present in the liquid growth medium prior to transferring the cells to solid medium. Consistent with the fact that $s w r A$ is required for swarming, the 

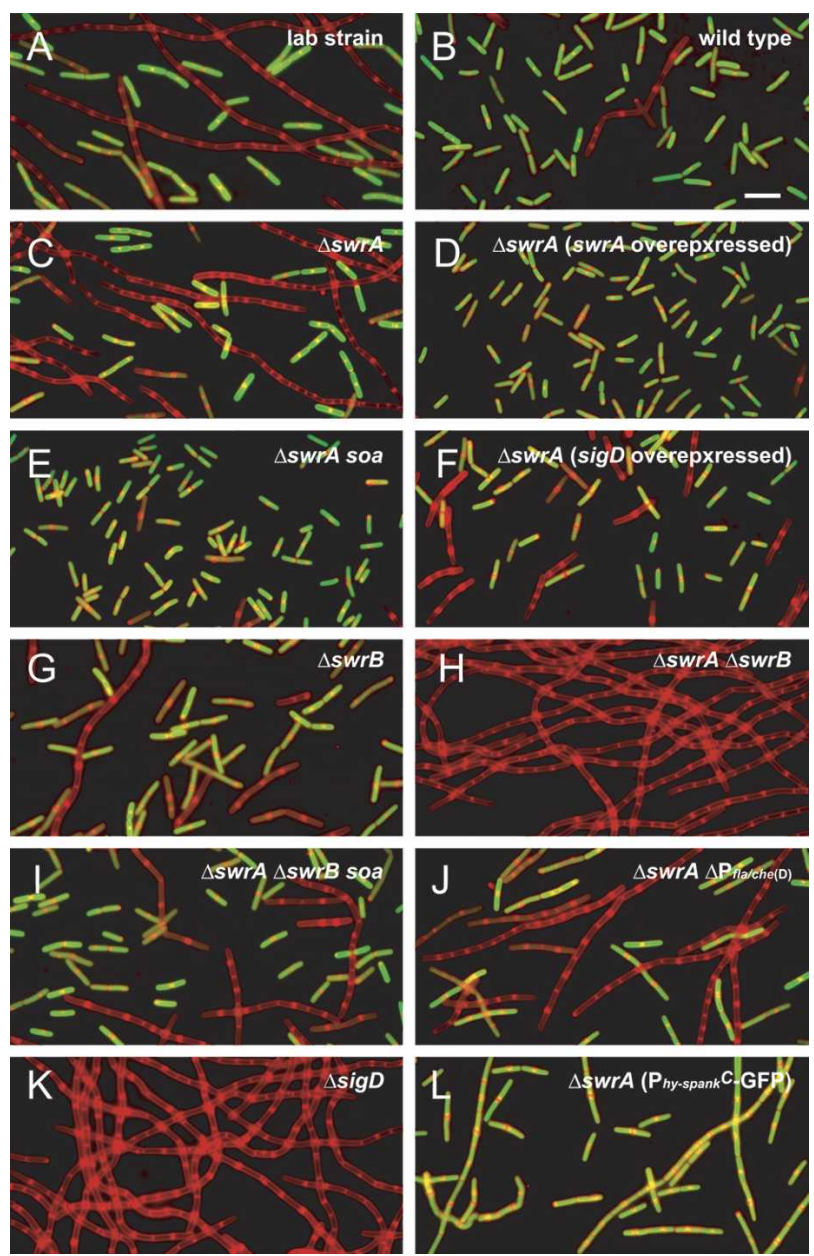

Figure 3. $\sigma^{\mathrm{D}}$-directed gene expression is subject to an ON/OFF switch that is influenced by SwrA and SwrB. Fluorescence micrographs were taken of mid-exponential phase $\left(\mathrm{OD}_{600}=1\right)$ cultures of the following strains: DS901 (A), DS908 (B), DS909 $(C)$ DS933 $(D), \operatorname{DS} 973(E), \operatorname{DS} 934(F), \operatorname{DS} 1488(G)$, DS1489 $(H), \operatorname{DS} 1512(I), \operatorname{DS} 1539(J), \operatorname{DS} 1543(K)$, and DS910 $(L)$. All strains contained $\mathrm{P}_{\text {hag }}-g f p$ except DS910 $(L)$, which contained $\mathrm{P}_{\text {hy-spank }}{ }^{\mathrm{C}}$-gfp. Membranes were stained with FM4-64 and false-colored in red. GFP signals were false-colored in green. Bar, $5 \mu \mathrm{m}$.

resulting strain (DS526) failed to exhibit surface motility on swarm agar plates in the absence of inducer (Fig. 5A). However, when grown in liquid medium fortified with IPTG, the ability of the cells to swarm when subsequently tested on solid medium was found to have been restored (Fig. 5A). Furthermore, whereas swarming in wild-type cells is preceded by a lag period that is dependent on the number of cells used in the inoculum (Kearns and Losick 2003; Shimada et al. 2004), the swarming lag of DS526 was found to be dependent on the IPTG concentration. Indeed, at the highest levels of inducer, the swarming lag was completely abolished (Fig. $5 \mathrm{~A})$. Based on the observation that overexpression of swrA both abolishes the swarming lag and causes hyperflagellation, it seems possible that high levels of SwrA bypass both the cell density and surface requirements for entry into the swarming state and produce differentiated "swarm cells" in liquid medium.

A suppressor mutation bypasses the role of SwrA in swimming and swarming

To investigate the mechanism by which SwrA acts, we looked for extragenic suppressors of the swarming defect in SwrA mutants. To do so, we took advantage of the requirement for swrA in surface motility to select for mutants that had acquired the capacity to swarm in the presence of a null mutation of the gene. When a swrAnull mutant was inoculated in the center of a swarm agar plate, the cells initially grew as a tight central colony and failed to completely colonize the surface of the plate. However, after $48 \mathrm{~h}$, flares of cells that had regained the ability to swarm emerged from the central colony. Cells from four independently isolated suppressor mutants were clonally purified.

The results obtained with one such suppressor of swrA (soa) mutant were as follows. The mutant exhibited a phenotype that resembled that observed when $s w r A$ was overexpressed: The suppressor mutant swarmed without a lag (Fig. 5B), grew predominantly as single motile cells (Fig. 2E), and was hyperflagellated in liquid medium (Fig. 4), and $\sigma^{\mathrm{D}}$-directed gene transcription was uniform among cells in the population (Fig. 3E). That the soa suppressor mutant retained the original swrA-null mutation was confirmed by polymerase chain reaction (PCR) analysis.

The soa suppressor mutation was found to reside within the promoter region $\left(\mathrm{P}_{\text {fla/che }}\right)$ upstream of a large

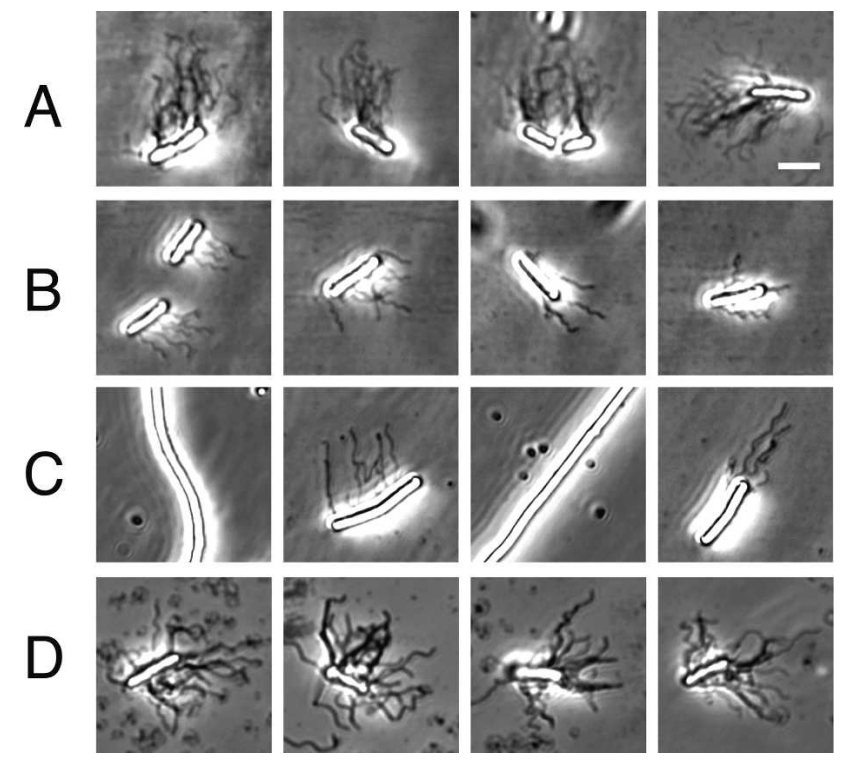

Figure 4. SwrA overexpression results in hyperflagellation. Flagellum staining was conducted on mid-exponential-phase cells grown in the presence of $1 \mathrm{mM}$ IPTG for the following: the SWrA-overexpressing strain DS526 $(A)$, the wild-type strain $3610(B)$, the swrA mutant DS215 $(C)$, and the swrA soa suppressor mutant strain DS726 (D). Bar, $2 \mu \mathrm{m}$. 


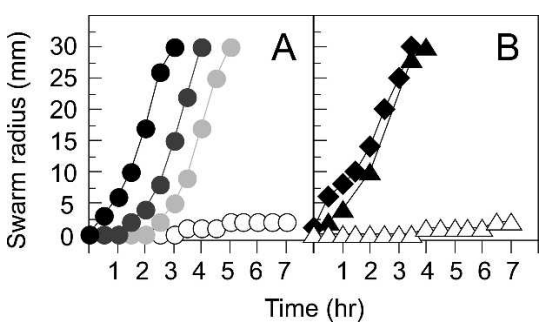

Figure 5. SwrA determines the duration of the swarming lag period. (A) The swarming behavior of strain DS526, a swrA-null mutant containing an IPTG-inducible copy of $s w r A$ (at amyE), in the presence of 0 (open circles), 0.01 (light-gray circles), 0.04 (dark-gray circles), and $0.1 \mathrm{mM}$ IPTG (solid circles). (B) The swarming behavior of a $s w r A$-null mutant (DS215, open triangles), a SwrA-null mutant with the soa bypass mutation (DS726, closed triangles), and a swrA-null mutant with an IPTG-inducible promoter driving expression of the fla/che operon and induced with $1 \mathrm{mM}$ IPTG (DS983, closed diamonds). Each point is the average of measurements from three experiments.

operon (the fla/che operon) that encodes 31 genes dedicated to flagellum biosynthesis and chemotaxis (Fig. 1; Márquez-Magaña and Chamberlin 1994; Kearns et al. 2004; Werhane et al. 2004). The region upstream of the fla/che operon contains two promoters: an operon-proximal promoter that is transcribed by $\sigma^{\mathrm{A}}$-containing RNA polymerase (herein called $\mathrm{P}_{\text {fla } / \text { che }(\mathrm{A})}$ ), and an operon distal promoter that is transcribed by $\sigma^{\mathrm{D}}$-containing RNA polymerase (herein called $\mathrm{P}_{f l a / c h e(\mathrm{D})}$ ) (Fig. 1; Estacio et al. 1998; West et al. 2000). The $\mathrm{P}_{\text {fla/che(A) }}$ promoter contains an imperfect -10 sequence (TAㄷAㄱ), and the soa suppressor mutant was found to contain a single base-pair change that created a -10 sequence that perfectly conformed to the consensus (TATAAT).

We predicted that the consequence of the soa mutation was to increase promoter strength. To test this hypothesis, reporter constructs were generated by fusing the promoter region from either the wild type or soa mutant to the lac $Z$ gene, which encodes $\beta$-galactosidase. The promoter from the soa mutant produced twice as much $\beta$-galactosidase activity as did the wild type (data not shown). That increased promoter activity was sufficient to bypass SWrA was confirmed by introducing a $\mathrm{P}_{\text {hy-spank }}$ promoter immediately upstream of the fla/che operon in a swrA mutant background. Enhanced expression of the fla/che operon was sufficient to restore swarming motility to the swrA mutant, and, as with the suppressor mutant, the swarming lag was abolished (Fig. 5B). From these data, we conclude that soa is a promoter up-mutation.

The remaining three suppressor-of-swrA mutations were also found to be located within or immediately upstream of the $\mathrm{P}_{\text {fla/che }}$ promoter region. One was identical to the base-pair change in the $\mathrm{P}_{f l a / c h e(\mathrm{~A})}$ promoter described above. The second was a deletion of the 3 '-region of the gene $(\operatorname{cod} Y)$ immediately upstream of the fla/che operon and its rho-independent transcriptional terminator. A similar deletion has been shown to increase ex- pression of the fla/che operon by readthrough from upstream transcription (Amati et al. 2004). The final suppressor was also a large deletion spanning $\operatorname{cod} Y$ and likely the transcriptional terminator, but the precise boundaries of the deletion were not determined. Thus all four suppressor mutations support the conclusion that increased expression of the fla/che operon is sufficient to bypass the requirement for swrA.

Next, we investigated whether the $\sigma^{\mathrm{A}}$-directed $\mathrm{P}_{\text {fla/che(A) }}$ promoter was the target of SwrA. To do this, $\mathrm{P}_{\text {fla/che }(\mathrm{A})}$ (which had been separated from $\mathrm{P}_{\text {fla/che }(\mathrm{D})}$ ) was fused to $l a c Z$ and introduced into the chromosome at the amyE locus. Expression of the $\mathrm{P}_{\text {fla/che }(\mathrm{A})}-$-lac $Z$ fusion was found to be threefold lower in a strain mutant for swrA and $\sim 50 \%$ higher when $s w r A$ was overexpressed using the $\mathrm{P}_{\text {hy-spank }}-S W r A$ contruct (which had been inserted into the chromosome at the $\operatorname{thr} C$ locus) (Fig. 6B; Supplementary Table S1). The effect on the $\mathrm{P}_{\text {fla/che(A) }}$ promoter was specific as judged by the fact that SwrA did not en-

A

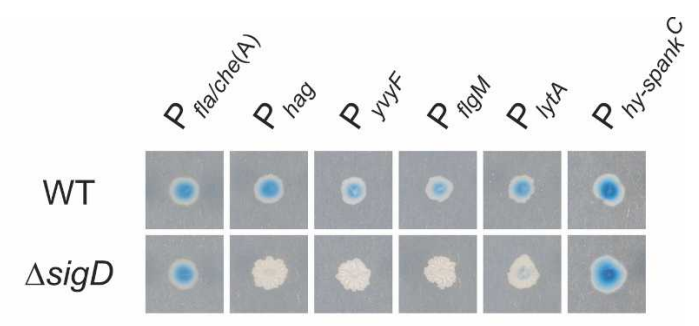

B

swrA overexpressed $\square$ wild type $\quad \square \Delta$ swrA

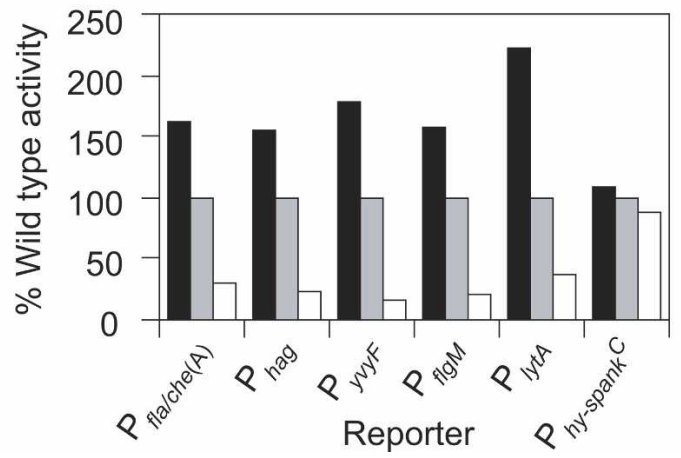

Figure 6. SwrA stimulates transcription from the $\mathrm{P}_{\text {fla/che }(\mathrm{A})}$ promoter and indirectly stimulates transcription from $\sigma^{\mathrm{D}}$-controlled promoters. (A) Wild-type or $\Delta$ sigD mutant colonies containing the indicated promoter region fused to the $1 a c Z$ gene and grown on LB medium containing $80 \mu \mathrm{g} / \mathrm{mL} \mathrm{X-gal.} \mathrm{The} \mathrm{fol-}$ lowing strains were used to generate the images: $\mathrm{P}_{\text {fla/che }(\mathrm{A})}$ (DS1421 and DS1423), $\mathrm{P}_{\text {hag }}$ (DS793 and DS965), $\mathrm{P}_{\text {yvyF }}$ (DS847 and DS964), $\mathrm{P}_{f l g M}$ (DS811 and DS968), $\mathrm{P}_{\text {lytA }}$ (DS794 and DS966), and $\mathrm{P}_{\text {hy-spank }}{ }_{\mathrm{C}}$ (DS871 and DS880). Colonies that were white demonstrate that $\sigma^{\mathrm{D}}$ was required for the transcription from the indicated promoter. $(B)$ The relative levels of $\beta$-galactosidase activity derived from the indicated reporter in a strain overexpressing swrA (black bars), a wild-type strain (gray bars), or a $\triangle s w r A$ mutant (white bars). The activity for each reporter was normalized to the wild-type level of $100 \%$. Values for the $\beta$-galactosidase activities used to generate the bar graph are in Supplementary Table S1. 
hance transcription from another promoter transcribed by $\sigma^{\mathrm{A}}$-containing RNA polymerase $\left(\mathrm{P}_{\text {hy-spank }}{ }^{\mathrm{C}}\right)$ (Fig. $\left.6 \mathrm{~B}\right)$. We conclude that SwrA acts as a positive regulator of the fla/che operon by stimulating transcription from the $\mathrm{P}_{\text {fla/che(A) }}$ promoter.

\section{SwrA and SigD direct the transcription of partially overlapping sets of genes}

To compare the patterns of SwrA- and $\sigma^{\mathrm{D}}$-directed gene transcription on a genome-wide basis, we carried out two kinds of transcriptional profiling experiments. In one, RNA from mid-exponential-phase cells of a swrA mutant was compared with RNA from mid-exponentialphase cells in which $s w r A$ was overexpressed. In the other, RNA from mid-exponential-phase cells of a sigD mutant was compared with RNA from mid-exponentialphase cells in which $\operatorname{sig} D$ was overexpressed. The results show that the patterns of SwrA- and $\sigma^{\mathrm{D}}$-activated transcription overlapped extensively in that SwrA stimulated the expression of many of the members of the $\sigma^{\mathrm{D}}$ regulon (Table 1; Supplementary Table S2). That SwrA stimulates transcription of $\sigma^{\mathrm{D}}$-controlled genes was confirmed by the use of lac $Z$ fusions to four promoters $\left(\mathrm{P}_{\text {hag }}, \mathrm{P}_{\text {yvyF }}, \mathrm{P}_{f l g M}\right.$, and $\left.\mathrm{P}_{\text {lytA }}\right)$ known to be under the direct control of the alternative $\sigma$ factor (Fig. 6; Mirel and Chamberlin 1989; Lazarevic et al. 1992; Mirel et al. 1994; Estacio et al. 1998).

A simple explanation for these results is that SwrA stimulates transcription from $\mathrm{P}_{\text {fla/che(A) }}$ and thereby indirectly enhances $\sigma^{\mathrm{D}}$-directed transcription by promoting transcription through $\operatorname{sig} D$, which is the penultimate gene in the fla/che operon (Fig. 1). Despite the presence of the $\mathrm{P}_{\text {fla/che(D) }}$ promoter, transcription of the fla/che operon was only weakly enhanced by $\sigma^{\mathrm{D}}$, not meeting the 2.5-fold threshold of significance set in our microarray experiments. However, this result was not unexpected as $\mathrm{P}_{f 1 a / c h e(\mathrm{D})}$ is much weaker than $\mathrm{P}_{f l a / c h e(\mathrm{~A})}$ and was known from earlier work to make only a minor contribution to transcription of the fla/che operon (West et al. 2000). This was confirmed in our present investigation by the use of a $\mathrm{P}_{\text {fla/che }(\mathrm{D})}-$ lac $Z$ fusion, which generated 88 Miller units of activity, as compared to a $\mathrm{P}_{\text {fla/che }(\mathrm{A})}-1$ lacZ fusion, which generated 515 Miller units of activity (Supplementary Table S1).

As the overexpression of $s w r A$ stimulates the expression of $\operatorname{sig} D$, we wondered whether the overexpression of $\operatorname{sig} D$ alone would be sufficient to bias the population in the direction of $\sigma^{\mathrm{D}}$-ON cells. Unlike the case for swrA overexpression in which $\mathrm{P}_{\text {hag }}-g f p$ was uniformly expressed in almost all cells in the population (Fig. 3D), overexpression of $\operatorname{sig} D$ was not sufficient to produce a uniform population of cells in the $\sigma^{\mathrm{D}}$-ON state (Figs. 2F, $3 F)$. From this we conclude that an additional gene(s) under SwrA control contributes to biasing cells to the $\sigma^{\mathrm{D}}$-ON state. Genes within the fla/che operon were likely candidates as the soa suppressor up-regulated the expression of this operon and strongly biased the population to the $\sigma^{\mathrm{D}}-\mathrm{ON}$ state.

\section{SwrB also contributes to $\sigma^{D}$-directed gene expression}

In previous work we identified a gene called $s w r B$ that is required for swarming but not swimming motility (Kearns et al. 2004). The $s w r B$ gene is located immediately downstream of, and is contranscribed with, $\operatorname{sig} D$ in the fla/che operon (Fig. 1; Werhane et al. 2004). In light of our results with SwrA, we wondered whether SwrB might also contribute to $\sigma^{\mathrm{D}}$-directed gene expression during growth. To answer this question, we monitored $\sigma^{\mathrm{D}}$-directed gene expression using both the $\mathrm{P}_{\text {hag }}-g f p$ fusion/reporter and a $\sigma^{\mathrm{D}}$-dependent lac $Z$ reporter. In the absence of SwrB, we observed only a slight reduction in the number of cells in the population in which $\sigma^{\mathrm{D}}$ was active and there was a slight decrease in overall $\sigma^{\mathrm{D}}$ activity (Figs. 2G, 3G; Supplementary Table S1). Strikingly, however, $\sigma^{\mathrm{D}}$ activity was almost completely abolished in cells that were doubly mutant for SwrA and SwrB (Figs. 2H, 3H; Supplementary Table S1). Unlike the swrA mutation, the $s w r B$ mutation did not affect expression from the $\mathrm{P}_{\text {fla/che(A) }}$ promoter (Supplementary Table S1). Evidently, SwrB does contribute to $\sigma^{\mathrm{D}}$-directed gene expression, but the contribution of SwrB is chiefly masked by the contribution of SwrA.

The simplest interpretation of these results is that SwrB is largely dispensable for $\sigma^{\mathrm{D}}$-directed gene expression under conditions in which $\sigma^{\mathrm{D}}$ is abundant due to high levels of $\operatorname{sig} D$ transcription. However, under conditions in which SwrA is absent and therefore $\sigma^{\mathrm{D}}$ levels are low, SwrB plays a critical role in $\sigma^{\mathrm{D}}$-directed gene expression. In keeping with this interpretation, the soa promoter up-mutation, which bypasses the dependence of the $\mathrm{P}_{\text {fla/che(A) }}$ promoter on SwrA, restored $\sigma^{\mathrm{D}}$-directed gene expression to a $s w r A$ swrB double mutant (Figs. 2I, $3 \mathrm{I}$ ). In this case, the soa mutation allowed $\operatorname{sig} D$ (and the rest of the fla/che operon) to be transcribed at a high level in the absence of SwrA, which is consistent with the hypothesis that at high levels of $\sigma^{\mathrm{D}}$, the role of SwrB in $\sigma^{\mathrm{D}}$-directed gene expression is dispensable.

\section{Biasing cell population heterogeneity requires SwrB}

As noted above, overexpressing $s w r A$ or bypassing $s w r A$ by means of a promoter up-mutation (soa) suppressed heterogeneity, resulting in a cell population that was almost exclusively in the $\sigma^{\mathrm{D}}$-ON state (Fig. 3D). Yet, overexpressing sigD alone (by use of the $\mathrm{P}_{\text {hy-spank }}-$ sigD construct) failed to do so (Fig. 3F). Evidently, suppressing cell population heterogeneity requires enhanced transcription not only of $\operatorname{sig} D$ but also of an additional gene(s) in the fla/che operon. An appealing candidate for this gene is $s w r B$, as $s w r B$ lies immediately downstream of, and is cotranscribed with, sigD, and hence SwrA and soa would be expected to enhance its transcription as well. In support of this hypothesis, the promoter up-mutation soa was unable to generate a largely homogeneous population of $\sigma^{\mathrm{D}}$-ON cells when the fla/che operon was mutant for $s w r B$ (Figs. 2I, 3I). We conclude that driving the population in the direction of $\sigma^{\mathrm{D}}$-ON cells requires high levels of both $\sigma^{\mathrm{D}}$ and of its activator, SwrB. Simultaneous overexpression of $\operatorname{sig} D$ and $\operatorname{swr} B$ alone was not, however, 
Table 1. Genes activated by SwrA and SigD

\begin{tabular}{|c|c|c|c|c|c|c|c|}
\hline Gene & $\begin{array}{l}\text { SwrA } \\
\text { ratio }^{\text {a }}\end{array}$ & $\begin{array}{l}\text { SigD } \\
\text { ratio }^{\text {b }}\end{array}$ & Function $^{\mathrm{c}}$ & Gene & $\begin{array}{l}\text { SwrA } \\
\text { ratio }^{a}\end{array}$ & $\begin{array}{l}\text { SigD } \\
\text { ratio }^{b}\end{array}$ & Function $^{\mathrm{c}}$ \\
\hline \multicolumn{4}{|c|}{ Genes activated by SwrA } & \multicolumn{4}{|c|}{ Genes activated by SwrA and SigD } \\
\hline cheA & 4.1 & $<$ & fla/che (chemotaxis) & $\operatorname{aco} A$ & 4.9 & 6.2 & Acetoin biosynthesis \\
\hline cheB & 5.9 & $<$ & fla/che (chemotaxis) & $\operatorname{app} A$ & 4.5 & 2.9 & Oligopeptide-binding protein \\
\hline cheC & 6.3 & $<$ & fla/che (chemotaxis) & cheD & 6.2 & 3.0 & fla/che (chemotaxis) \\
\hline cheY & 8.1 & $<$ & fla/che (chemotaxis) & cheV & 6.5 & 14.3 & Chemotaxis \\
\hline$f \lg B$ & 7.2 & $<$ & fla/che (basal body) & cheW & 9.3 & 3.6 & fla/che (chemotaxis) \\
\hline$f \lg C$ & 8.4 & $<$ & fla/che (basal body) & comGG & 3.0 & 3.5 & Competence \\
\hline$f \lg E$ & 11.4 & $<$ & fla/che (hook) & coms & 3.4 & 4.7 & Competence regulator \\
\hline flhB & 12.0 & $<$ & fla/che (flagellum associated) & $f \lg G$ & 4.1 & 2.6 & Flagellum basal body (flhO) \\
\hline$f l h F$ & 11.1 & $<$ & fla/che (flagellum associated) & $f l g K$ & 5.6 & 4.5 & Flagellum hook \\
\hline fliE & 9.0 & $<$ & fla/che (hook-basal body, minor) & $f \lg L$ & 6.3 & 5.2 & Flagellum hook \\
\hline fliF & 7.4 & $<$ & fla/che (basal body) & $f \lg M$ & 3.6 & 2.6 & $\sigma^{\mathrm{D}}$ anti-sigma factor \\
\hline fliG & 9.2 & $<$ & fla/che (motor switch) & flhA & 6.9 & 2.9 & fla/che (flagellum associated) \\
\hline fliI & 9.3 & $<$ & fla/che (ATP synthase) & $f 1 h P$ & 3.1 & 2.6 & Flagellum basal body (minor) \\
\hline flit & 3.1 & $<$ & fla/che (flagellum assembly) & fliD & 5.1 & 6.9 & Flagellum hook \\
\hline fliK & 6.2 & $<$ & fla/che (hook assembly) & $\mathrm{fliH}$ & 5.1 & 2.7 & fla/che (flagellum assembly) \\
\hline fliL & 3.1 & $<$ & fla/che (flagellum assembly) & flis & 7.4 & 6.8 & Flagellar protein \\
\hline flim & 9.6 & $<$ & fla/che (motor switch) & fliT & 5.4 & 7.5 & Flagellar protein \\
\hline fliP & 2.8 & $<$ & fla/che (flagellum assembly) & $\operatorname{ger} D$ & 5.7 & 6.0 & Germination protein \\
\hline fliQ & 8.7 & $<$ & fla/che (flagellum assembly) & $\operatorname{glg} D$ & 8.6 & 28.4 & Glycogen biosynthesis \\
\hline fliR & 10.7 & $<$ & fla/che (flagellum assembly) & hag & 11.0 & 34.6 & Flagellin \\
\hline$f l i Y$ & 9.4 & $<$ & fla/che (motor switch) & hemAT & 10.0 & 60.7 & MCP \\
\hline fliz & 7.7 & $<$ & fla/che (flagellum assembly) & lytA & 5.0 & 2.8 & Autolysin production \\
\hline $\operatorname{sig} D$ & 6.6 & $32.6^{\mathrm{d}}$ & fla/che $\left(\sigma^{\mathrm{D}}\right)$ & lytB & 5.5 & 4.2 & Autolysin production \\
\hline$s w r B$ & 8.0 & $<$ & fla/che (swarming motility) & lytD & 9.2 & 18.1 & Autolysin \\
\hline$y l x F$ & 3.8 & $<$ & fla/che (unknown) & lytF & 4.8 & 5.4 & Autolysin \\
\hline \multirow[t]{2}{*}{$y l x G$} & 10.4 & $<$ & fla/che (hook assembly) & $m c p A$ & 11.4 & 11.5 & MCP \\
\hline & & & & $m c p B$ & 9.8 & 5.6 & MCP \\
\hline acoL & 4.8 & $<$ & Acetoin biosynthesis & $m c p C$ & 4.7 & 3.8 & $\mathrm{MCP}$ \\
\hline $\operatorname{araR}$ & 4.3 & $<$ & Transcriptional regulator & $\operatorname{mot} A$ & 5.6 & 3.8 & Flagellar motor component \\
\hline $\cot A$ & 7.7 & $<$ & Spore coat protein & $\operatorname{mot} B$ & 10.0 & 43.6 & Flagellar motor component \\
\hline lytC & 3.5 & $<$ & Autolysin & phrF & 4.6 & 3.9 & Cell-cell signaling peptide \\
\hline $\operatorname{rod} A$ & 3.5 & $<$ & Cell shape protein & $\operatorname{tas} A$ & 2.7 & 3.3 & Biofilm matrix component \\
\hline$y c g M$ & 5.8 & $<$ & Similar to proline oxidase & $\operatorname{tlp} A$ & 5.4 & 3.0 & MCP homolog \\
\hline$y \operatorname{cgN}$ & 5.3 & $<$ & Similar to dehydrogenase & $\operatorname{tlp} B$ & 13.8 & 6.4 & MCP homolog \\
\hline$y d c L$ & 3.0 & $<$ & Similar to integrase & $\operatorname{tlp} C$ & 10.5 & 7.8 & MCP homolog \\
\hline$y d c M$ & 3.1 & $<$ & Similar to prophage immunity & ydeQ & 5.3 & 5.7 & Similar to oxidoreductase \\
\hline$y f i V$ & 2.8 & $<$ & Transcriptional regulator & $y d f Q$ & 6.9 & 12.7 & Similar to thioredoxin \\
\hline ykuU & 2.7 & $<$ & Similar to peroxiredoxin & yest & 3.1 & 3.8 & Similar to acetyltransferase \\
\hline уоан & 30.0 & $<$ & $\mathrm{MCP}$ & $y f m S$ & 12.3 & 8.2 & MCP homolog \\
\hline yold & 8.4 & $<$ & Unknown & $y f m T$ & 6.0 & 5.7 & Similar to dehydrogenase \\
\hline yprB & 3.1 & $<$ & Unknown & $y f n H$ & 5.8 & 27.1 & Similar to dehydrogenase \\
\hline yt1Q & 2.9 & $<$ & Unknown & $y h x D$ & 4.3 & 6.3 & Similar to dehydrogenase \\
\hline yusE & 2.7 & $<$ & Similar to thioredoxin & yis $S$ & 4.6 & 6.3 & Similar to dehydrogenase \\
\hline$y v b Y$ & 6.2 & $<$ & Unknown & yolA & 6.5 & 16.7 & Unknown \\
\hline$y v y F$ & 3.6 & $<$ & Unknown & yolc & 7.9 & 24.2 & Unknown \\
\hline$y w j F$ & 3.2 & $<$ & Similar to iron-sulfur reductase & yrvI & 3.4 & 3.1 & Similar to dehydrogenase \\
\hline \multirow[t]{9}{*}{ ywrO } & 3.4 & $<$ & Similar to oxidoreductase & $y s c B$ & 5.1 & 2.8 & Unknown \\
\hline & & & & yvaB & 3.9 & 3.8 & Similar to dehydrogenase \\
\hline & & & & $y v a Q$ & 7.6 & 10.8 & MCP homolog \\
\hline & & & & $y v b X$ & 7.9 & 15.5 & Similar to chitinase \\
\hline & & & & $y v i E$ & 4.2 & 5.1 & Unknown \\
\hline & & & & yvyC & 7.7 & 36.8 & Unknown \\
\hline & & & & yvyG & 6.1 & 12.6 & Unknown \\
\hline & & & & $y v z B$ & 7.7 & 13.6 & Similar to flagellin \\
\hline & & & & ywtD & 6.1 & 4.0 & Similar to murien hydrolase \\
\hline
\end{tabular}

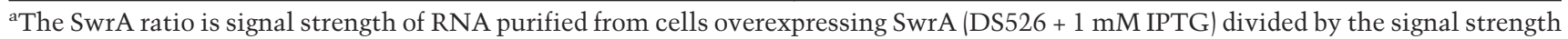
of RNA purified from cells mutant for SWrA (DS215). Values are the average of five replicates. $(<)$ A value $<2.5$.

${ }^{b}$ The SigD ratio is signal strength of RNA purified from cells overexpressing SigD (DS880 + $1 \mathrm{mM}$ IPTG) divided by the signal strength of RNA purified from cells mutant for sigD (DS323). Values are the average of 4 replicates. $(<)$ A value $<2.5$.

c(fla/che) Members of the fla/che operon. (MCP) methyl-accepting chemotaxis protein.

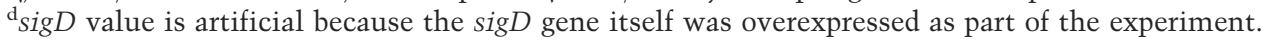


sufficient to suppress cell population heterogeneity (data not shown). We conclude from this that driving the cell population in the direction of $\sigma^{\mathrm{D}}$-ON cells requires overexpression of an additional yet-to-be-identified gene(s) in the fla/che operon.

\section{Discussion}

Cell population heterogeneity is governed by a biased bistable switch

We have discovered that individual growing cells of $B$. subtilis exist in two strikingly different states: a nomadic state in which the cells are motile and in which $\sigma^{\mathrm{D}}$ is active $\left(\sigma^{\mathrm{D}} \mathrm{ON}\right)$ and a sessile state in which the cells are attached to each other in long chains and in which $\sigma^{\mathrm{D}}$ is inactive $\left(\sigma^{\mathrm{D}} \mathrm{OFF}\right)$. In this way, B. subtilis appears to resemble the unrelated, dimorphic bacterium Caulobacter crescentus, which grows as morphologically and physiologically distinct motile and sessile cells. The ability to generate a mixed population of sessile and nomadic cells may confer on B. subtilis (and Caulobacter) the capacity both to exploit its present location as well as to disperse to new and perhaps more favorable niches.

In Caulobacter the generation of alternative cell types is hard-wired into the cell cycle (Skerker and Laub 2004). This is not the case in B. subtilis, and we propose instead that the formation of motile and sessile cell types by $B$. subtilis is mediated by a bistable switch that locks the activity of $\sigma^{\mathrm{D}}$ into an ON or OFF state (Ferrell 2002). In wild (undomesticated) strains, the switch is biased in the direction of the $\sigma^{\mathrm{D}}$-ON state by SwrA, a regulatory protein that stimulates expression of $\operatorname{sig} D$ by directly or indirectly enhancing transcription from the $\sigma^{\mathrm{A}}$-controlled, $\mathrm{P}_{\text {fla/che(A) }}$ promoter of the fla/che operon. Interestingly, SwrA lacks the hallmark features of many transcriptional activator proteins, such as a recognizable DNA-binding motif, and its mode of action in stimulating transcription from the $\mathrm{P}_{\text {fla/che }} \mathrm{A}$ ) promoter is unknown. The discovery that SwrA enhances expression of the fla/che operon and biases cells to the $\sigma^{\mathrm{D}}$-ON state also provides insight into its role in surface motility by suggesting that entry into the swarming state requires that a high proportion of the cell population is motile and hyperflagellated.

Consistent with its role in stimulating transcription of the fla/che operon and biasing the bistable switch, the gene for SwrA was recently shown to be the site of a classic mutation called ifm (for increased frequency of motility) that enhances the abundance (frequency) of motile cells and the number of flagella per cell (Grant and Simon 1969; Senesi et al. 2004). Laboratory strains typically carry a frameshift mutation in swrA (Kearns et al. 2004), and ifm was shown to be a single base-pair deletion that eliminated the frameshift (Calvio et al. 2005). Thus, ifm can now be understood as a reversion mutation that restored the mutant gene for SwrA in laboratory strains to its wild-type state.

Interestingly, overexpression of $s w r A$ can drive cell population heterogeneity almost exclusively in the direction of the $\sigma^{\mathrm{D}}$-ON state during growth in liquid me- dium and eliminate the characteristic lag associated with differentiation into the swarming state under conditions of growth on a surface. To do so, however, SwrA must stimulate the expression not only of $\operatorname{sig} D$ but also that of an additional gene in the fla/che operon, swrB, which is ordinarily required for swarming but not swimming. Our present results show that SwrB acts by enhancing $\sigma^{\mathrm{D}}$-directed gene expression. Like SwrA, SwrB does not resemble other proteins in the databases, and its mode of action in augmenting $\sigma^{\mathrm{D}}$ activity, and whether it does so in a direct or indirect fashion, are unknown.

Werhane et al. (2004) have reported that a $s w r B\left(y l_{x} L\right)$ mutation alone caused a severe reduction in $\sigma^{\mathrm{D}}$-directed gene expression (in contrast to the subtle effect we observed) but oddly only a modest defect in motility. This work was, however, conducted with a laboratory strain in which the allelic state of $s w r A$ was not assessed. As noted above, laboratory strains frequently contain a frameshift mutation in swrA that reverts at high frequency (Kearns et al. 2004; Calvio et al. 2005). Thus, the strong dependence of $\sigma^{\mathrm{D}}$-directed gene expression on swrB observed by Werhane et al. (2004) may have been seen with cells that were mutant for $s w r A$. Likewise, the swimming behavior seen by the authors might have resulted from selection under conditions that favor swimming for $s w r A^{+}$revertants. In any event, our results agree with those of Werhane et al. (2004) in pointing to a role for SwrB in the activation of $\sigma^{\mathrm{D}}$.

\section{A regulatory chain model for the contribution of SwrA and $S w r B$ to gene expression}

In summary, we propose a simple regulatory chain for the contribution of SwrA and SwrB to the expression of genes involved in flagellum biosynthesis and motility (Fig. 1). SwrA stimulates the transcription of the fla/che operon from the $\mathrm{P}_{\text {fla/che(A) }}$ promoter, thereby enhancing the transcription of the $\operatorname{sig} D$ and $\operatorname{swr} B$ genes. The $\sigma^{\mathrm{D}}$ factor, in turn, augmented by the action of SwrB, directs transcription of autolysin genes and the remaining genes involved in motility. Neither SwrA nor SwrB alone is needed for $\sigma^{D}$ activation or motility, but SwrA is required for driving a high proportion of the cell population into the $\sigma^{\mathrm{D}}$-ON state, and both SwrA and SwrB are needed to achieve the high level of flagellation required for surface motility.

Bistability does not depend on SwrA and SwrB and is not mediated by autogenous regulation

Despite the contributions of SwrA and SwrB to $\sigma^{\mathrm{D}}$ synthesis and activity, neither is an essential part of the mechanism that subjects $\sigma^{\mathrm{D}}$-directed gene expression to bistability. Thus, cells lacking SwrA and SwrB, which are normally devoid of $\sigma^{\mathrm{D}}$ activity, regained the capacity to swim and express $\sigma^{\mathrm{D}}$-controlled genes when highlevel transcription of the fla/che operon was restored by the presence of the soa promoter up-mutation. Yet, soaharboring cells that were doubly mutant for SwrA and SwrB exhibited bistability, generating a mixture of single, swimming cells in which $\sigma^{\mathrm{D}}$ activity was $\mathrm{ON}$ and sessile chains of cells in which $\sigma^{\mathrm{D}}$ activity was OFF (Fig. 3I). 
A distinctive feature of the bistable switch governing $\sigma^{\mathrm{D}}$ activity is that it is manifest during the exponential phase of growth. Two other examples of bistable switches in B. subtilis, those governing the activation of the master regulators for competence (ComK) (Maamar and Dubnau 2005; Smits et al. 2005) and sporulation (Spo0A) (Veening et al. 2005), operate under conditions in which cells are entering stationary phase. In contrast, cell population heterogeneity with respect to the state of $\sigma^{\mathrm{D}}$ activity was seen under (presumably) steady-state conditions in which all cells in the population were actively growing.

The bistable switch for $\sigma^{\mathrm{D}}$ also differs from those for ComK and Spo0A in that it does not appear to operate by means of autogenous regulation. Compelling evidence indicates that bistability for the activation of ComK and Spo0A is governed by positive feedback loops in which the transcription factors stimulate the expression of their own structural genes (directly in the case of former and indirectly in the case of latter) (Maamar and Dubnau 2005; Smits et al. 2005; Veening et al. 2005). This is apparently not the case for $\sigma^{\mathrm{D}}$ as we now explain. First, although the fla/che operon is preceded by a $\sigma^{\mathrm{D}}$-controlled promoter, $\mathrm{P}_{f l a / c h e(\mathrm{D})}$ is much weaker than the SwrA-controlled $\mathrm{P}_{\text {fla/che(A) }}$ promoter (West et al. 2000; Supplementary Table S1) and is unlikely to contribute significantly to the overall level of expression of $\operatorname{sig} D$ (and $s w r B)$. Indeed, and as demonstrated by gene microarray experiments, overexpression of $\operatorname{sig} D$ had little effect on transcription of the fla/che operon (Table 1). Second, it was previously shown that deletion of $\mathrm{P}_{\text {fla/che(D) }}$ has no consequence on motility (West et al. 2000). We have confirmed and extended this observation by building a mutation that entirely removed $\mathrm{P}_{\text {fla/che(D) }}$ (see Supplemental Material) and found that it had little or no effect on motility or bistability (Figs. 2J, 3J). Third, gene microarray experiments failed to reveal evidence for any other $\sigma^{\mathrm{D}}$-controlled promoter in the operon driving expression of $\operatorname{sig} D$ (and swrB) (data not shown). Evidently, then, bistability does not occur by an autogenous control mechanism in which $\sigma^{\mathrm{D}}$ stimulates transcription of its own structural gene.

\section{A hook-basal body model for bistability}

What then is the basis for the bistable switch if, as we surmise, bistability occurs at a step downstream of the transcription of the $\operatorname{sig} D$ gene? One possibility is that the switch operates at the level of the synthesis or activity of $\sigma^{\mathrm{D}}$ by a positive feedback loop involving the assembly of the flagellum basal body. It is known from work with Salmonella that the activity of the $\sigma$ factor for flagellum biosynthesis (called $\sigma^{\mathrm{F}}$ in Gram-negative bacteria) is dependent on the assembly of the flagellum basal body by a pathway involving the anti-sigma factor FlgM (Komeda 1986; Hughes et al. 1993; Kutsukake 1994; Karlinsey et al. 2000). We speculate that an analogous pathway (indeed, possibly involving the $B$. subtilis homolog of FlgM, which is known to be an antagonist of $\sigma^{D}$ ) (Caramori et al. 1996) sets up a self-reinforcing cycle that stimulates the synthesis and/or activity of $\sigma^{\mathrm{D}}$. Many of the genes for the basal body (those in the fla/che operon) are not under $\sigma^{\mathrm{D}}$ control, but two major hook-basal body genes, flgG and $f \lg K$, lie outside of the operon and are transcribed in a $\sigma^{\mathrm{D}}$-dependent manner as judged by gene microarray analysis (Fig. 1; Table 1; Zuberi et al. 1991; Kubori et al. 1997; Serizawa et al. 2004). Thus, $\sigma^{\mathrm{D}}$-directed transcription of $f 1 g G$ and $f 1 g K$ would stimulate basal body formation, which, in turn, would stimulate the synthesis and/ or activity of $\sigma^{\mathrm{D}}$. We note that suppression of bistability required overexpression not only of the genes for $\sigma^{D}$ and SwrB but also of additional unidentified gene(s) in the fla/che operon. We speculate that this additional gene(s) could be one or more of the other hook-basal body genes near the $5^{\prime}$-end of the fla/che operon (Fig. 1). Finally, the higher-order assembly of the basal body would introduce cooperativity into the bistable switch, thereby helping to achieve sharp ON/OFF control of $\sigma^{\mathrm{D}}$ activity.

In addition to the bistable switch, $\sigma^{\mathrm{D}}$ activation is subject to a phase-variation control mechanism. As we have seen, the bistable switch is strongly biased by the action of the product of $s w r A$, which is subject to a phase-variation switch that is thought to operate by means of "slipped strand" mispairing during replication (Henderson et al. 1999; Kearns et al. 2004). Thus, the capacity to exist in alternative motile and sessile life styles is subject to two levels of stochastic control, a high-frequency bistable (and presumably epigenetic) switch that ensures that the population is a mixture of two cell types and a low-frequency phase variation (genetic) switch that biases the proportion of the two cell types in one direction or the other.

Lastly, we speculate that the population bias between swimming and chaining cells may be influenced by environmental conditions. Under some conditions, wild strains of $B$. subtilis are capable of swarming in a robust manner on surfaces, a behavior that involves the formation of groups of motile cells that are joined together in assemblies called rafts. Here we have demonstrated that SwrA biases the population in favor of motile cells, which, in turn, contribute to raft formation and swarming motility. Under other conditions, wild strains are capable of forming architecturally complex communities (biofilms) in which long chains of nonmotile cells are tightly bundled together through the formation of an extracellular matrix (Branda et al. 2001, 2004; Kearns et al. 2005). It will be interesting to determine whether some proteins required for biofilm formation serve to bias the cell population in favor of chaining. Opposing mechanisms that increase the proportion of swimming cells or chaining cells may be of central importance in determining which multicellular behavior, swarming or biofilm formation, is adopted for a particular environment.

\section{Materials and methods}

\section{Strains and growth conditions}

B. subtilis PY79, 3610, and derivatives thereof were grown at $37^{\circ} \mathrm{C}$ in Luria-Bertani (LB) (10 g of tryptone, $5 \mathrm{~g}$ of yeast extract, $5 \mathrm{~g}$ of $\mathrm{NaCl}$ per liter) broth or LB plates supplemented with $1.5 \%$ Bacto agar. When appropriate, antibiotics were included at the 
following concentrations: $10 \mu \mathrm{g} / \mathrm{mL}$ tetracycline, $100 \mu \mathrm{g} / \mathrm{mL}$ spectinomycin, $5 \mu \mathrm{g} / \mathrm{mL}$ chloramphenicol, $5 \mu \mathrm{g} / \mathrm{mL}$ kanamycin, and $1 \mu \mathrm{g} / \mathrm{mL}$ erythromycin plus $25 \mu \mathrm{g} / \mathrm{mL}$ lincomycin (mls). Isoproyl $\beta$-D-thiogalactopyranoside (IPTG, Sigma) or 5-bromo4-chloro-3-indolyl $\beta$-D-galactopyranoside (X-Gal, Sigma) was added to either liquid or solid medium at the indicated concentration when appropriate.

\section{Microscopy}

For phase contrast images, cells were grown to $1 \mathrm{OD}_{600}$, and 5 $\mu \mathrm{L}$ of culture was spotted on a glass microscope slide and immobilized with a poly-L-lysine-treated glass coverslip. Samples were observed under phase contrast at $1000 \times$ magnification using an Olympus BX60 microscope and recorded with Metamorph image capture software (Universal Imaging).

For fluorescence microscopy, $1.0 \mathrm{~mL}$ of broth culture was harvested at $1.0 \mathrm{OD}_{600}$, and washed twice in $1.0 \mathrm{~mL}$ of phosphatebuffered saline (137 mM NaCl, $2.7 \mathrm{mM} \mathrm{KCl}, 10 \mathrm{mM} \mathrm{Na}_{2} \mathrm{HPO}_{4}$, and $2 \mathrm{mM} \mathrm{KH}_{2} \mathrm{PO}_{4}$ ), $\mathrm{PBS}$ buffer. The suspension was pelleted, resuspended in $50 \mu \mathrm{L}$ of PBS buffer containing $1 \mu \mathrm{g} / \mathrm{mL}$ FM4-64 (Molecular Probes), and incubated for $5 \mathrm{~min}$ at room temperature. Three microliters of suspension were placed on a microscope slide and immobilized with a poly-L-lysine-treated coverslip. Fluorescence microscopy was performed with an Olympus BX60 microscope with Mercury lamp. Fluorescent signals were viewed using the phase contrast objective UplanF1 100x and visualized using a U-WIBA filter cube (GFP, excitation filter 460-490 nm, barrier filter $515-550 \mathrm{~nm}$ ) or a U-WG filter cube (FM4-64, excitation filter $510-550 \mathrm{~nm}$, barrier filter $>590 \mathrm{~nm}$ ). Images were captured, falsecolored, and overlaid using Metamorph software, exported as TIFF files, and adjusted with Adobe Photoshop software.

Flagella were stained according to Mayfield and Inniss (1977). Stain was prepared by mixing 10 parts mordant $(2 \mathrm{~g}$ of tannic acid, $10 \mathrm{~mL}$ of $5 \%$ phenol, $10 \mathrm{~mL}$ of saturated aqueous $\left.\mathrm{AlKO}_{8} \mathrm{~S}_{2} \cdot 12 \mathrm{H}_{2} \mathrm{O}\right)$ with 1 part stain $(12 \%$ crystal violet in ethanol). Three microliters of $1.0 \mathrm{OD}_{600}$ broth-grown cells were applied to a microscope slide and covered with a $22 \mathrm{~mm} \times 40 \mathrm{~mm}$ coverslip. The slide was propped vertically, and $10 \mu \mathrm{L}$ of dye was applied to the top edge of the coverslip to stain the sample by capillary action. Samples were observed at $1000 \times$ magnification under phase contrast using an Olympus BX60 microscope and recorded with Metamorph image capture software.

\section{Swarm expansion assay}

Cells were grown to mid-log phase at $37^{\circ} \mathrm{C}$ in LB broth and resuspended to $10 \mathrm{OD}_{600}$ in PBS buffer containing 0.5\% India ink (Higgins). Freshly prepared LB containing $0.7 \%$ agar $(25 \mathrm{~mL} /$ plate) was dried for $30 \mathrm{~min}$ in a laminar flow hood, centrally inoculated with $10 \mu \mathrm{L}$ of the cell suspension, dried for another $10 \mathrm{~min}$, and incubated at $37^{\circ} \mathrm{C}$. The India ink demarked the origin of the colony, and swarm radii were measured relative to the origin. For consistency, an axis was drawn on the back of the plate, and swarm radii measurements were taken along this transect.

\section{Strain construction}

The details of strain construction are given in Supplemental Materials and Methods S1. All primers used in this study are listed in Supplementary Table S3. All plasmids used in this study are listed in Supplementary Table S4. All strains used in this study are listed in Table 2.

Sequencing $P_{\mathrm{fla} / \mathrm{che}}$

A PCR product containing the $\mathrm{P}_{\text {fla/che }}$ promoter region was amplified from either 3610 or DS726 B. subtilis chromosomal
Table 2. Strains $^{a}$

\begin{tabular}{|c|c|}
\hline Strain & Genotype \\
\hline 3610 & Wild type \\
\hline PY79 & $s w r A^{\text {PY79 }} s f p^{0}$ [laboratory strain] \\
\hline DS215 & $\Delta s w r A::$ tet \\
\hline DS323 & $\Delta \operatorname{sig} D::$ tet \\
\hline DS526 & $\Delta s w r A::$ tet amyE $:: \mathrm{P}_{\text {hy-spank }}-s w r A$ spec \\
\hline DS726 & $\Delta s w r A::$ tet soa swr ${ }^{+}$suppressor \\
\hline DS791 & amyE $:: \mathrm{P}_{\text {fla/che }}-1 a c Z$ cat \\
\hline DS792 & amyE $:: \mathrm{P}_{\text {yvyF }}-$ lac $Z$ cat \\
\hline DS793 & amyE:: $\mathrm{P}_{\text {hag }}-1 a c Z$ cat \\
\hline DS794 & amyE $:: \mathrm{P}_{l_{y t A}}-1 a c Z$ cat \\
\hline DS811 & amyE $:: \mathrm{P}_{f l g} M^{-} l a c Z$ cat \\
\hline DS846 & $\Delta s w r A::$ tet $a m y E:: \mathrm{P}_{\text {fla } / \text { che }}-1 a c Z$ cat \\
\hline DS847 & $\Delta s w r A::$ tet $a m y E:: \mathrm{P}_{y v y F}-1 a c Z$ cat \\
\hline DS848 & $\Delta s w r A::$ tet amyE $:: \mathrm{P}_{\text {hag }}-1 a c Z$ cat \\
\hline DS849 & $\Delta s w r A::$ tet amyE $:: \mathrm{P}_{1 y t A}-1 a c Z$ cat \\
\hline DS852 & $\Delta s w r A::$ tet amyE $:: \mathrm{P}_{f l g M}-1 a c Z$ cat \\
\hline DS871 & amyE $:: \mathrm{P}_{\text {hy-spank }}-1 a c Z$ spec \\
\hline DS873 & $\Delta s w r A::$ tet $a m y E:: \mathrm{P}_{\text {hy-spank }} \mathrm{C}^{\mathrm{C}}-1 a c Z$ spec \\
\hline DS880 & $\Delta \operatorname{sig} A::$ tet amyE $:: \mathrm{P}_{\text {hy-spank }}-\operatorname{sig} D$ kan \\
\hline DS885 & amyE $:: \mathrm{P}_{\text {fla } / \text { che }}-1 a c Z$ cat thrC $:: \mathrm{P}_{\text {hy-spank }}-s w r A \mathrm{mls}$ \\
\hline DS886 & amyE $:: \mathrm{P}_{\text {yvy }}-1$ ac $Z$ cat thrC:: $\mathrm{P}_{\text {hy-spank }}-$ swrA mls \\
\hline DS887 & amyE $:: \mathrm{P}_{\text {hag }}-1 a c Z$ cat thrC $:: \mathrm{P}_{\text {hy-spank }}-S w r A$ mls \\
\hline DS888 & amyE $:: \mathrm{P}_{\text {lyt } A}-1 a c Z$ cat thrC $:: \mathrm{P}_{\text {hy-spank }}-s w r A$ mls \\
\hline DS890 & amyE $:: \mathrm{P}_{f l g M}-1 a c Z$ cat thrC:: $\mathrm{P}_{\text {hy-spank }}-s w r A$ mls \\
\hline DS891 & $\begin{array}{l}\text { amyE }:: \mathrm{P}_{\text {hy-spank }}{ }^{\mathrm{C}}-\text { lacZ spec thrC:: } \mathrm{P}_{\text {hy-spank }}-S w r A \\
\text { mls }\end{array}$ \\
\hline DS901 & $\begin{array}{l}s w r A^{\mathrm{PY} 79} s f p^{0} \text { amyE }:: \mathrm{P}_{\text {hag }} \text {-GFP cat [laboratory } \\
\text { strain] }\end{array}$ \\
\hline DS908 & amyE $:: \mathrm{P}_{\text {hag }}$-GFP cat \\
\hline DS909 & $\Delta s w r A::$ tet amyE $:: \mathrm{P}_{\text {hag }}$-GFP cat \\
\hline DS910 & $\Delta s w r A::$ tet amyE $:: \mathrm{P}_{\text {hy-spank }}{ }^{\mathrm{C}}$-GFP spec \\
\hline DS933 & $\begin{array}{l}\Delta s w r A:: \text { tet amyE }:: \mathrm{P}_{\text {hag }} \text {-GFP cat } \\
\text { thrC }:: \mathrm{P}_{\text {hy-spank }}-s w r A \mathrm{mls}\end{array}$ \\
\hline DS934 & 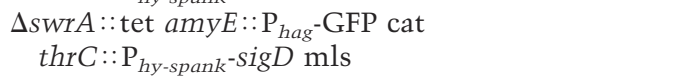 \\
\hline DS964 & $\Delta \operatorname{sig} D::$ tet $a m y E:: \mathrm{P}_{y v y F}-1 a c Z$ cat \\
\hline DS965 & $\Delta \operatorname{sig} D::$ tet $a m y E:: \mathrm{P}_{\text {hag }}-1 a c Z$ cat \\
\hline DS966 & $\Delta \operatorname{sig} D::$ tet amyE $:: \mathrm{P}_{\text {lyt }}-1 a c Z$ cat \\
\hline DS968 & $\Delta \operatorname{sig} D::$ tet $a m y E:: \mathrm{P}_{f l g M}-1 a c Z$ cat \\
\hline DS970 & $\Delta \operatorname{sig} D::$ tet $a m y E:: \mathrm{P}_{\text {hy-spank }}{ }^{\mathrm{C}}-1 a c Z$ spec \\
\hline DS973 & $\Delta s w r A::$ tet soa amyE $:: \mathrm{P}_{\text {hag }}$-GFP cat \\
\hline DS983 & $\Delta$ swrA :: tet $\mathrm{P}_{\text {fla/che }} \Omega \mathrm{P}_{\text {hy-spank }}-f l a /$ che operon spec \\
\hline DS1416 & amyE $:: \mathrm{P}_{f l a / c h e(\mathrm{D})^{-}-1 a c Z}$ cat \\
\hline DS1417 & $\Delta s w r A::$ tet amyE $:: \mathrm{P}_{\text {fla/che }(\mathrm{D})^{-}-1 a c Z \text { cat }}$ \\
\hline DS1420 & amyE $:: \mathrm{P}_{\text {fla/che }(\mathrm{D})}-1 a c Z$ cat thrC:: $\mathrm{P}_{\text {hy-spank }}-S w r A \mathrm{mls}$ \\
\hline DS1421 & amyE $:: \mathrm{P}_{f l a / c h e}(\mathrm{~A})^{-1 a c Z}$ cat \\
\hline DS1422 & $\Delta s w r A::$ tet $a m y E:: \mathrm{P}_{\text {fla } / \text { che }(\mathrm{A})}-1 a c Z$ cat \\
\hline DS1423 & $\Delta \operatorname{sig} D::$ tet $a m y E:: \mathrm{P}_{\text {fla } / \text { che }(\mathrm{A})}-1 a c Z$ cat \\
\hline DS1425 & amyE $\left.:: \mathrm{P}_{\text {fla/che }(\mathrm{A})}\right)^{-1 a c Z}$ cat thrC $:: \mathrm{P}_{\text {hy-spank }}-S w r A \mathrm{mls}$ \\
\hline DS1426 & amyE $:: \mathrm{P}_{\text {fla/che }}^{\text {soa }}-1 a c Z$ cat \\
\hline DS1488 & SwrB $\Omega$ Tn1107 spec amyE $:: \mathrm{P}_{\text {hag }}$-GFP cat \\
\hline DS1489 & $\Delta s w r A::$ tet $s w r B \Omega T n 1107$ spec amyE $:: \mathrm{P}_{\text {hag }}$-GFP cat \\
\hline DS1512 & $\begin{array}{l}\Delta s w r A:: \text { tet soa } s w r B \Omega T n 1107 \text { spec amyE:: } \mathrm{P}_{\text {hag }} \text {-GFP } \\
\quad \text { cat }\end{array}$ \\
\hline DS1529 & $\begin{array}{l}\Delta s w r A:: \text { tet thrC }:: \mathrm{P}_{\text {hy-spank }}-\operatorname{sig} D s w r B \mathrm{mls} \\
\quad \text { amyE }:: \mathrm{P}_{\text {hag }} \text { GFP cat }\end{array}$ \\
\hline DS1539 & $\Delta s w r A::$ tet $\Delta P_{f l a / c h e(\mathrm{D})}$ amyE $:: \mathrm{P}_{\text {hag }}$-GFP cat \\
\hline DS1543 & $\Delta \operatorname{sig} D::$ tet amyE $:: \mathrm{P}_{\text {hag }}$-GFP cat \\
\hline MF341 & amyE $:: \mathrm{P}_{\text {hy-spank }}{ }^{\mathrm{C}}$-GFP spec [laboratory strain] \\
\hline MF342 & amyE $:: \mathrm{P}_{\text {hy-spank }} \mathrm{C}-$ lac $Z$ spec [laboratory strain] \\
\hline
\end{tabular}

${ }^{a}$ All strains are in the wild-type 3610 background unless otherwise indicated. 
DNA using the primers codYF/PflacheR. The $\mathrm{P}_{\text {fla/che }}$ PCR product was then sequenced using either primer individually.

\section{$\beta$-Galactosidase assay}

One milliliter of cells were harvested from a mid-log phase $\left(\mathrm{OD}_{600} \sim 1.0\right)$ culture grown in $\mathrm{LB}$ broth shaken at $37^{\circ} \mathrm{C}$, harvested, and resuspended in an equal volume of $\mathrm{Z}$ buffer $(40 \mathrm{mM}$ $\mathrm{NaH}_{2} \mathrm{PO}_{4}, 60 \mathrm{mM} \mathrm{Na} \mathrm{HPO}_{4}, 1 \mathrm{mM} \mathrm{MgSO}$, $10 \mathrm{mM} \mathrm{KCl}, 38$ $\mathrm{mM} \beta$-mercaptoethanol). To each sample, lysozyme was added to a final concentration of $0.2 \mathrm{mg} / \mathrm{mL}$ and incubated at $30^{\circ} \mathrm{C}$ for $15 \mathrm{~min}$. Each sample was diluted appropriately in $500 \mu \mathrm{L}$ of $\mathrm{Z}$ buffer and the reaction was started with $100 \mathrm{~mL}$ of $4 \mathrm{mg} / \mathrm{mL}$ 2-nitrophenyl $\beta$-D-galactopyranoside (in Z buffer) and stopped with $250 \mathrm{~mL}$ of $1 \mathrm{M} \mathrm{Na}_{2} \mathrm{CO}_{3}$. The $\mathrm{OD}_{420}$ of the reaction mixtures was recorded, and the $\beta$-galactosidasespecific activity was calculated according to the equation: $\left[\mathrm{OD}_{420} /\left(\right.\right.$ time $\left.\left.\times \mathrm{OD}_{600}\right)\right] \times$ dilution factor $\times 1000$.

\section{Transcriptional profiling assay}

Total RNA was isolated from mid-exponential-phase cultures grown in LB broth supplemented with 1 mM IPTG. RNA was isolated using the hot acid/phenol method (protocol available at http://mcb.harvard.edu/losick/fawcettpaper/RNAprep.htm). RNA purified from strain DS215 ( $\Delta s w r A:$ :tet) was compared with strain DS526 ( $\Delta S w r A::$ tet amyE:: $\mathrm{P}_{\text {hy-spank }}-S w r A$ cat $)$, and RNA purified from DS323 ( $\Delta$ sigD ::tet) was compared with strain DS880 ( $\Delta$ sigD :: tet amyE:: $\mathrm{P}_{\text {hy-spank }}-\operatorname{sig} D$ cat). A total of $20 \mu \mathrm{g}$ of RNA from each strain was used to apply to the array. The volume of each RNA sample was brought up to $14 \mu \mathrm{L}$ using DEPC-treated $\mathrm{H}_{2} \mathrm{O}$ and $1 \mu \mathrm{L}$ of $1 \mathrm{mg} \mathrm{mL}^{-1}$ of random primer was added. The samples were incubated at $70^{\circ} \mathrm{C}$ for $10 \mathrm{~min}$ and then incubated on ice for $2 \mathrm{~min}$. To the appropriate tube, $2 \mu \mathrm{L}$ of [Cy5]dUTP and [Cy3]dUTP were added along with $12 \mu \mathrm{L}$ of reaction mix $(2.5 \times$ Invitrogen First Strand buffer, $25 \mathrm{mM}$ DTT, $2 \mathrm{mM}$ ATP, $2 \mathrm{mM}$ CTP, $2 \mathrm{mM}$ GTP, $0.8 \mathrm{mM}$ TTP, $100 \mathrm{U}$ of Roche Protector RNase inhibitor). After addition of [Cy5]dUTP and [Cy3]dUTP, the reactions were shielded from light for the rest of the procedure. To the reaction mixture, $200 \mathrm{U}$ of SuperScript II RNase H-free reverse transcriptase (Invitrogen) were added. The tubes were incubated at room temperature for 10 min, then incubated at $42^{\circ} \mathrm{C}$ for $2 \mathrm{~h}$, and finally incubated at $70^{\circ} \mathrm{C}$ for $15 \mathrm{~min}$. After incubating the reactions, $3 \mathrm{U}$ of RNase $\mathrm{H}$ (Invitrogen) was added, and the mixtures were placed at $37^{\circ} \mathrm{C}$ for $20 \mathrm{~min}$. The RNA samples to be compared were combined, and a QIAGEN PCR purification kit was used to purify the cDNA probes. A Speedvac was then applied to the samples until $5 \mu \mathrm{L}$ of probe remained. To the remaining probe, $20 \mu \mathrm{g}$ of yeast tRNA, $5 \times$ SSC, $0.5 \%$ SDS, and $33 \%$ formamide was added. The reactions were heated to $100^{\circ} \mathrm{C}$ for $1 \mathrm{~min}$, spun briefly, and applied to an oligo array containing $>99 \%$ of the annotated protein-coding genes of the B. subtilis genome (Britton et al. 2002). Prior to hybridization, the slides were rinsed in rinsing solution $(0.2 \%$ SDS $)$ for 4 min and washed twice in $\mathrm{ddH}_{2} \mathrm{O}$ for $2 \mathrm{~min}$ each. The slides were then blocked for 15 min using aldehyde blocking solution (1.0 g of $\mathrm{NaBH}_{4}, 0.75 \times \mathrm{PBS}, 25 \%$ ethanol), and the rinse and washing steps were repeated. The slides were dried before applying probe. Hybridizations were performed overnight in CMT-hybridization chambers (Corning) submerged in a waterbath at $42^{\circ} \mathrm{C}$. After hybridization, unbound probe was washed off the slides by rinsing for $1 \mathrm{~min}$ in wash buffer 1 ( $2 \times$ SSC and $0.2 \%$ SDS), $1 \mathrm{~min}$ in wash buffer $2(2 \times$ SSC), and $1 \mathrm{~min}$ in wash buffer $3(0.2 \times$ SSC $)$. Finally, the slides were dried and scanned on a GenePix 4000B scanner (Axon Instruments). Images were processed and analyzed with GenePix 4.0 software
(Axon Instruments, Inc.). Spots containing low signals were excluded from further analysis. In our final data set, we included only genes in which there was a 2.5 -fold change in expression, as seen using data from at least three replicates of the transcriptional profiling experiment.

\section{Acknowledgments}

We thank K. Blair, P. Eichenberger, M. Fujita, C. Fuqua, D. Rudner, and A.L. Sonenshein for reagents, constructs, and assistance; E. Quordokus and Y. Brun for use of their microscope for the experiment of Supplementary Figure S1; and D. Dubnau, M. Fujita, M. Laub, D. Rudner, and L. Shapiro for critical comments on the manuscript. This work was supported by an NIH National Research Service Award GM66612 to D.B.K. and a National Institutes of Health grant GM18568 to R.L.

\section{References}

Albertini, A.M., Caramori, T., Crabb, W.D., Scoffone, F., and Galizzi, A. 1991. The flaA locus of Bacillus subtilis is part of a large operon coding for flagellar structures, motility functions, and an ATPase-like polypeptide. J. Bacteriol. 173: 3573-3579.

Amati, G., Bisicchia, P., and Galizzi, A. 2004. DegU-P represses expression of the motility fla-che operon in Bacillus subtilis. J. Bacteriol. 186: 6003-6014.

Balaban, N.Q., Merrin, J., Chait, R., Kowalik, L., and Leibler, S. 2004. Bacterial persistence as a phenotypic switch. Science 305: 1622-1625.

Blackman, S.A., Smith, T.J., and Foster, S.J. 1998. The role of autolysins during vegetative growth of Bacillus subtilis 168 . Microbiology 144: 73-82.

Branda, S.S., González-Pastor, J.E., Ben-Yehuda, S., Losick, R., and Kolter, R. 2001. Fruiting body formation by Bacillus subtilis. Proc. Nat1. Acad. Sci. 98: 11621-11626.

Branda, S.S., Gonzalez-Pastor, J.E., Dervyn, E., Ehrlich, D., Losick, R., and Kolter, R. 2004. Genes involved in the formation of structured multicellular communities by Bacillus subtilis. J. Bacteriol. 186: 3970-3979.

Britton, R.A., Eichenberger, P., González-Pastor, J.E., Fawcett, P., Monson, R., Losick, R., and Grossman, A.D. 2002. Genome-wide analysis of the stationary-phase $\sigma$ factor $(\sigma-\mathrm{H})$ regulon of Bacillus subtilis. J. Bacteriol. 184: 4881-4890.

Calvio, C., Celandroni, F., Ghelardi, E., Amati, G., Salvetti, S., Ceciliani, F., Galizzi, A., and Senesi, S. 2005. Swarming differentiation and swimming motility in Bacillus subtilis are controlled by $s w r A$, a newly identified dicistronic operon. $J$. Bacteriol. 187: 5356-5366.

Caramori, T., Barillà, D., Nessi, C., Sacchi, L., and Galizzi, A. 1996. Role of FlgM in $\sigma^{\mathrm{D}}$-dependent gene expression in $\mathrm{Ba}$ cillus subtilis. J. Bacteriol. 178: 3113-3118.

Chen, L. and Helmann, J.D. 1994. The Bacillus subtilis $\sigma^{\mathrm{D}}$ dependent operon encoding the flagellar proteins FliD, FliS, and FliT. J. Bacteriol. 176: 3093-3101.

Chung, J.D., Stephanopoulos, G., Ireton, K., and Grossman, A.D. 1994. Gene expression in single cells of Bacillus subtilis: Evidence that a threshold mechanism controls the initiation of sporulation. J. Bacteriol. 176: 1977-1984.

Estacio, W., Santa Anna-Arriola, S., Adedipe, M., and MárquezMagaña, L.M. 1998. Dual promoters are responsible for transcription initiation of the fla/che operon in Bacillus subtilis. J. Bacteriol. 180: 3548-3555.

Fein, J.E. 1979. Possible involvement of bacterial autolytic en- 
zymes in flagellar morphogenesis. J. Bacteriol. 137: 933-946.

Ferrell Jr., J.E. 2002. Self-perpetuating states in signal transduction: Positive feedback, double-negative feedback and bistability. Curr. Opin. Cell Biol. 14: 140-148.

Fujita, M., González-Pastor, J.E., and Losick, R. 2005. High- and low-threshold genes in the Spo0A regulon of Bacillus subtilis. J. Bacteriol. 187: 1357-1368.

González-Pastor, J.E., Hobbs, E.C., and Losick, R. 2003. Cannibalism by sporulating bacteria. Science 301: 510-513.

Grant, G.F. and Simon, M.I. 1969. Synthesis of bacterial flagella II. PBS1 transduction of flagella-specific markers in Bacillus subtilis. J. Bacteriol. 99: 116-124.

Hadden, C. and Nester, E.W. 1968. Purification of competent cells in the Bacillus subtilis transformation system. J. Bacteriol. 95: 876-885.

Haijema, B.-J., Hahn, J., Haynes, J., and Dubnau, D. 2001. A ComGA-dependent checkpoint limits growth during the escape from competence. Mol. Microbiol. 40: 52-64.

Haseltine-Cahn, F. and Fox, M.S. 1968. Fractionation of transformable bacteria from competent cultures of Bacillus subtilis on renografin gradients. J. Bacteriol. 95: 867-875.

Helmann, J.D., Márquez, L.M., and Chamberlin, M.J. 1988. Cloning, sequencing, and disruption of the Bacillus subtilis $\sigma^{28}$ gene. J. Bacteriol. 170: 1568-1574.

Henderson, I.R., Owen, P., and Nataro, J.P. 1999. Molecular switches-The ON and OFF of bacterial phase variation. Mol. Microbiol. 33: 919-932.

Hughes, K.T., Gillen, K.L., Semon, M.J., and Karlinsey, J.E. 1993. Sensing structural intermediates in bacterial flagellar assembly by export of a negative regulator. Science 262: $1277-1280$.

Karlinsey, J.E., Tanaka, S., Bettenworth, V., Yamaguchi, S., Boos, W., Aizawa, S.-I., and Hughes, K.T. 2000. Completion of the hook-basal body complex of the Salmonella typhimurium flagellum is coupled to $\mathrm{FlgM}$ secretion and fliC transcription. Mol. Microbiol. 37: 1220-1231.

Kearns D.B. and Losick, R. 2003. Swarming motility in undomesticated Bacillus subtilis. Mol. Microbiol. 49: 581-590.

Kearns, D.B., Chu, F., Rudner, R., and Losick, R. 2004. Genes governing swarming in Bacillus subtilis and evidence for a phase variation mechanism controlling surface motility. Mol. Microbiol. 52: 357-369.

Kearns, D.B., Chu, F., Branda, S.S., Kolter, R., and Losick, R. 2005. A master regulator for biofilm formation by Bacillus subtilis. Mol. Microbiol. 55: 739-749.

Keren, I., Shah, D., Spoering, A., Kaldalu, N., and Lewis, K. 2004. Specialized persister cells and the mechanism of multidrug tolerance in Escherichia coli. J. Bacteriol. 186: 8172-8180.

Komeda, Y. 1986. Transcriptional control of flagellar genes in Escherichia coli K-12. J. Bacteriol. 168: 1315-1318.

Kubori, T., Okumura, M., Kobayashi, N., Nakamura, D., Iwakura, M., and Aizawa, S.-I. 1997. Purification and characterization of the flagellar hook-basal body complex of $\mathrm{Ba}$ cillus subtilis. Mol. Microbiol. 24: 399-410.

Kutsukake, K. 1994. Excretion of the anti-sigma factor through a flagellar substructure couples flagellar gene expression with flagellar assembly in Salmonella typhimurium. Mol. Gen. Genet. 243: 605-612.

Lazarevic, V., Margot, P., Soldo, B., and Karamata, D. 1992. Sequencing and analysis of the Bacillus subtilis lytRABC divergon: A regulatory unity encompassing the structural genes of the N-acetylmuramoyl-L-alanine amidase and its modifier. J. Gen. Microbiol. 138: 1949-1961.

Maamar, H. and Dubnau, D. 2005. Bistability in the Bacillus subtilis K-state (competence) system requires a positive feedback loop. Mol. Microbiol. 56: 615-624.

Margot, P., Mauël, C., and Karamata, D. 1994. The gene of the $\mathrm{N}$-acetylglucosaminidase, a Bacillus subtilis 168 cell wall hydrolase not involved in vegetative cell autolysis. Mol. Microbiol. 12: 535-545.

Margot, P., Pagni, M., and Karamata, D. 1999. Bacillus subtilis 168 gene $l y t F$ encodes a $\gamma$-D-glutamate-meso-diaminopimelate muropeptidase expressed by the alternative $\sigma$ factor $\sigma^{\mathrm{D}}$. Microbiology 145: 57-65.

Márquez, L.M., Helmann, J.D., Ferrari, E., Parker, H.M., Ordal, G.W., and Chamberlin, M.J. 1990. Studies of $\sigma^{\mathrm{D}}$-dependent functions in Bacillus subtilis. J. Bacteriol. 172: 3435-3443.

Márquez-Magaña, L.M. and Chamberlin, M.J. 1994. Characterization of the $\operatorname{sig} D$ transcription unit of Bacillus subtilis. J. Bacteriol. 176: 2427-2434.

Mayfield, C.I. and Inniss, W.E. 1977. A rapid, simple method for staining bacterial flagella. Can. J. Microbiol. 23: 1311-1313.

Mirel, D.B. and Chamberlin, M.J. 1989. The Bacillus subtilis flagellin gene (hag) is transcribed by the $\sigma^{28}$ form of RNA polymerase. J. Bacteriol. 174: 3095-3101.

Mirel, D.B., Lauer, P., and Chamberlin, M.J. 1994. Indentification of flagellar synthesis regulatory and structural genes in a $\sigma^{\mathrm{D}}$-dependent operon of Bacillus subtilis. I. Bacteriol. 176: 4492-4500.

Nishihara T. and Freese, E. 1975. Motility of Bacillus subtilis during growth and sporulation. J. Bacteriol. 123: 366-371.

Senesi, S., Ghelardi, E., Celandroni, F., Salvetti, S., Parisio, E., and Galizzi, A. 2004. Surface-associated flagellum formation and swarming differentiation in Bacillus subtilis are controlled by the ifm locus. J. Bacteriol. 186: 1158-1164.

Serizawa, M., Yamamoto, H., Yamaguchi, H., Yasutaro, F., Kobayashi, K., Ogasawara, N., and Sekiguchi, J. 2004. Systematic analysis of SigD-regulated genes in Bacillus subtilis by DNA microarray and Northern blotting analyses. Gene 329: $125-136$.

Shimada, H., Ikeda, T., Wakita, J., Itoh, H., Kurosu, S., Hiramatsu, F., Nakatsuchi, M., Yamazaki, Y., Matsuyama, T., and Matsushita, M. 2004. Dependence of local cell density on concentric ring colony formation by bacterial species $\mathrm{Ba}$ cillus subtilis. J. Phys. Soc. Japan 73: 1082-1089.

Skerker, J.M. and Laub, M.T. 2004. Cell-cycle progression and the generation of asymmetry in Caulobacter crescentus. Nat. Rev. Microbiol. 2: 325-327.

Smits, W.K., Eschevins, C.C., Susanna, K.A., Bron, S., Kuipers, O.P., and Hamoen, L.W. 2005. Stripping Bacillus: ComK auto-stimulation is responsible for the bistable response in competence development. Mol. Microbiol. 56: 604-614.

Veening, J.-W., Hamoen, L.W., and Kuipers, O.P. 2005. Phosphatases modulate the bistable sporulation gene expression pattern in Bacillus subtilis. Mol. Microbiol. 56: 1481-1494.

Werhane, H., Lopez, P., Mendel, M., Zimmer, M., Ordal, G.W., and Márquez-Magaña, L.M. 2004. The last gene of the fla/ che operon in Bacillus subtilis, ylxL, is required for maximal $\sigma^{\mathrm{D}}$ function. J. Bacteriol. 186: 4025-4029.

West, J.T., Estacio, W., and Márquez-Magana, L. 2000. Relative roles of the fla/che $\mathrm{P}_{\mathrm{A}}, \mathrm{P}_{\mathrm{D}-3}$, and $\mathrm{P}_{\text {sigD }}$ promoters in regulating motility and sigD expression in Bacillus subtilis. J. Bacteriol. 182: 4841-4848.

Zuberi, A.R., Ying, C., Weinreich, M.R., and Ordal, G.W. 1990. Transcriptional organization of a cloned chemotaxis locus of Bacillus subtilis. J. Bacteriol. 172: 1870-1876.

Zuberi, A.R., Ying, C., Bischoff, D.S., and Ordal, G.W. 1991. Gene-protein relationships in the flagellar hook-basal body complex of Bacillus subtilis: Sequences of the $f \lg B, f l g C$, $f l g G$, fliE, and fliF genes. Gene 101: 23-31. 


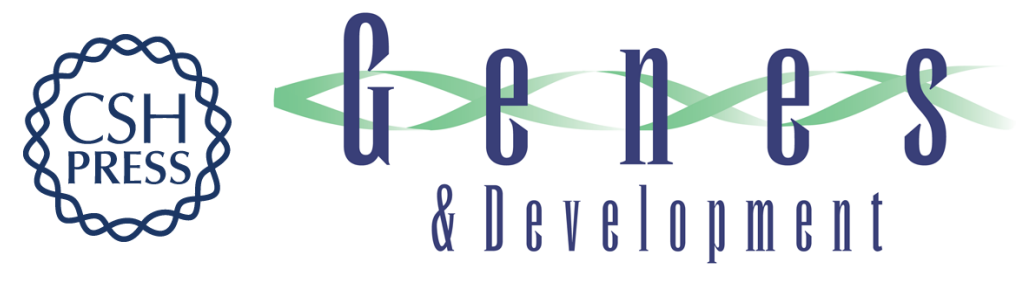

\section{Cell population heterogeneity during growth of Bacillus subtilis}

Daniel B. Kearns and Richard Losick

Genes Dev. 2005, 19:

Access the most recent version at doi:10.1101/gad.1373905

Supplemental

Material

References

License

Email Alerting Service
http://genesdev.cshlp.org/content/suppl/2005/11/30/19.24.3083.DC1

This article cites 51 articles, 29 of which can be accessed free at: http://genesdev.cshlp.org/content/19/24/3083.full.html\#ref-list-1

Receive free email alerts when new articles cite this article - sign up in the box at the top right corner of the article or click here.

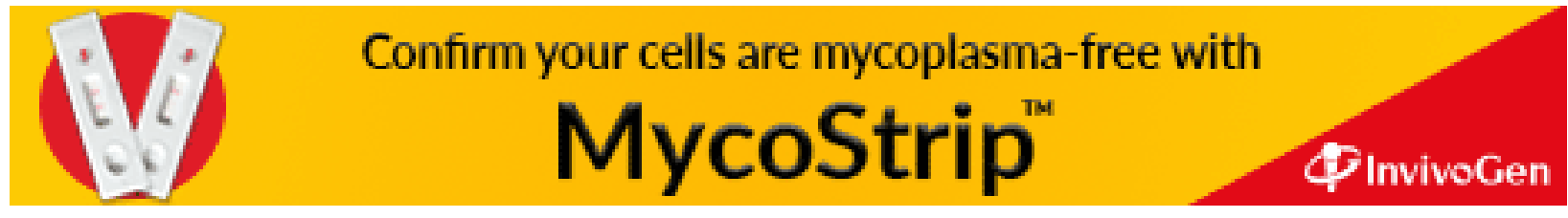

